SPECIAL ISSUE ARTICLE

\title{
Collective victimhood and acknowledgement of outgroup suffering across history: Majority and minority perspectives
}

\author{
Eva G.T. Green*, Emilio Paolo Visintin*, Antoaneta Hristova†, Ana Bozhanova†, Adrienne Pereira* \& \\ Christian Staerklé* \\ * University of Lausanne, Switzerland \\ † Bulgarian Academy of Sciences, Bulgaria
}

\author{
Correspondence \\ Eva G. T. Green, Institute of Psychology, \\ University of Lausanne, Bâtiment Géopolis, \\ 1015 Lausanne, Switzerland. \\ E-mail: eva.green@unil.ch \\ Received: 14 January 2016 \\ Accepted: 25 July 2016 \\ http://dx.doi.org/10.1002/ejsp.2237 \\ Keywords: collective victimhood, \\ acknowledgment of outgroup suffering, \\ group-based forgiveness, collective guilt, \\ historical memory, Bulgaria
}

\begin{abstract}
This paper examines how temporally differentiated representations of ingroup victimhood and acknowledgment of outgroup suffering relate to present intergroup attitudes. A mixed-methods research was conducted in Bulgaria where both the ethnic majority and the Bulgarian Turkish minority can be viewed as victims and perpetrators in the past. Multigroup path models (Study 1$)$ revealed that for the majority $(N=192)$ collective victimhood was positively related to social distance through reduced forgiveness and through reduced collective guilt for a different historical era. Acknowledgment of outgroup suffering, in turn, was associated with reduced social distance through heightened guilt and through forgiveness for another era. Among the Bulgarian Turks $(N=160)$, the result pattern differed. Collective victimhood was unrelated to forgiveness. Moreover, the relationship between guilt and social distance was positive. Semi-directive interviews (Study 2) revealed different meanings attributed to the events by the two groups. The impact of intertwined historical representations on current-day prejudice is discussed in light of power asymmetry between groups.
\end{abstract}

Conflicts between groups typically have longstanding consequences on intergroup attitudes. Collective victimhood represents a shared narrative in the memory of a group-based on real and reconstructed experiences of ingroup suffering-in which the rival group is portrayed as having inflicted intentional harm to the ingroup (e.g., Bar-Tal, Chernyak-Hai, Schori, \& Gundar, 2009). Groups often have a deep sense of victimhood irrespective of their roles in the conflict even without personal experiences of the conflict (Staub, 2006). The role played by the ingroup in outgroup suffering, however, is usually less present in these narratives (Bilali \& Ross, 2012). Yet, both acknowledgement of outgroup suffering and collective victimhood of the ingroup have important implications on how the aftermath of conflicts is managed, thereby shaping future intergroup relations (e.g., Noor, Shnabel, Halabi, \& Nadler, 2012; Vollhardt, 2012). Furthermore, across history, power relations between groups change such that a group can be a victim at one point in time and a perpetrator at another time. Representations of history convey shared understandings within a group of past conflicts and define the role of both in- and outgroups in terms of perpetrators and victims in these events (Liu \& Hilton, 2005).

Past intergroup configurations and experiences of victimhood and perpetratorhood are likely to continue to influence present-day intergroup attitudes. This research examines the role of group-based emotions in explaining how representations of past suffering link to present intergroup outcomes for both majorities and minorities (Iyer $\&$ Leach, 2008). More specifically, we investigate the role of group-based forgiveness and guilt in the relationship between perceived collective victimhood and acknowledgment of past outgroup suffering on the one hand, and present-day social distance, on the other. ${ }^{1}$ While prior research has demonstrated links between these constructs, the novel contributions of the current study are fourfold. First, the study was conducted in Bulgaria-an understudied intergroup setting-among ethnic Bulgarians (the national majority) and Bulgarian Turks (an ethnic minority). Both the ethnic majority and the Turkish minority can be viewed as victims and perpetrators in intergroup conflicts involving these two groups at different moments in history. Second, we examined in parallel the process through which representations of ingroup victimhood and acknowledgment of outgroup suffering that took place at different historical periods coexist within a group and trigger emotional reactions related to both events. Third, the research simultaneously considered the perspective of the two rival groups in two different conflicts. Fourth,

\footnotetext{
${ }^{1}$ Social distance is a form of prejudice assessing the degree of avoidance of different types of proximity and contact with outgroup members (Weaver, 2008; see Bogardus, 1967).
} 
we used a mixed-methods approach (Creswell \& Plano Clark, 2007) that allows highlighting the interdependence and dynamic nature of victimhood and perpetratorhood across time. In Study 1, with a crosssectional survey, we test the relationships between concepts of theoretical interest related to past victimhood and perpetratorhood and current-day social distance across the two groups. Study 2 seeks to gain a deeper understanding of these processes by exploring the potentially different meaning making of ingroup victimhood and acknowledgment of outgroup suffering across the two groups with semi-directive interviews.

\section{Intergroup Context in Bulgaria}

Before examining the psychological processes related to collective victimhood and acknowledgement of outgroup suffering, the Bulgarian intergroup context and varying functions of collective victimhood (Bar-Tal et al., 2009) for the two groups are introduced. Bulgaria is a demographically multicultural nation with a long-standing history of interethnic tensions between the ethnic Bulgarian majority and the Bulgarian Turkish minority. The Ottoman Rule refers to the historical period starting from the conquest of the Bulgarian Empire by the Ottoman Empire in 1396 until the Liberation of Bulgaria in 1878 when the modern Bulgarian state was founded. Bulgarian Turks are descendants of Turks who settled in Bulgaria during the Ottoman Rule. They are Bulgarian citizens constituting the largest ethnic minority in today's Bulgaria (9\% of the population). Yet, throughout the country, the Bulgarian majority is the advantaged, dominant group relative to the more disadvantaged and subordinate Turkish minority group (see for example Pamporov, 2010, for differences in education and income levels between the groups).

In the eyes of many majority members, Bulgarian Turks are still associated to oppressors even 140 years after the end of the Ottoman rule (Mudde, 2005). Victimhood resulting from the Ottoman Rule remains present in everyday discourse, partly because Bulgarian national identity is strongly anchored in the shared representations of heroic liberation from the Ottoman rule. This representation is cultivated in the literature, in historical movies as well as in history school books (Todorova, 2004), thereby maintaining the sense of victimhood and legitimizing negative stances towards Bulgarian Turks (Bar-Tal et al., 2009; see also Reicher \& Hopkins, 2001 for the building of national identity). Attempts to deflate national myths or to include alternative minority representations of victimhood have been met with fierce criticism, advocates of such views being often portrayed as national traitors (Pashova et al., 2013).

Conversely, during the communist era coercive assimilationist policies were implemented by the Bulgarian government culminating in the mid-1980s with the so-called Rebirth process (also called the Revival process) in which Bulgarian Turks were targets of forced assimilation into mainstream Bulgarian culture (Crampton, 1997). Bulgarian Turks were for example forced by means of official intimidation to adopt Bulgarian names. Protests were met with violent repression by the regime and around 350000 Bulgarian Turks exiled to Turkey (though many returned disappointed). Even after the transition from the socialist to the democratic system, the breakdown of long-standing harmonious relations between ethnic Bulgarians and Bulgarians Turks increased social distance between the groups (Elcheva, 2005). In 2010, the Bulgarian parliament acknowledged that some acts that occurred during the Rebirth era were a form of ethnic cleansing, but there have been no official investigations of these acts. Though the Rebirth process is hardly present in everyday and public discourse, Bulgarian Turks are occasionally reminded of collective victimhood by politicians, in particular from the Movement of Rights and Freedoms party, a party driving mainly the interests of Bulgarian Turks. This sense of collective victimhood helps coping with the recent past and fosters solidarity among Bulgarian Turks (Elcheva, 2005; see Bar-Tal et al., 2009). However, unlike for the national majority, collective victimhood is not associated with a nationbuilding project among the Bulgarian Turkish population.

The ubiquitous one-sided official representation of history reflects the current-day power asymmetry between the two groups. Considering the perspectives of both the dominant and the subordinate group (Sidanius \& Pratto, 1999; see Demoulin, Leyens, \& Dovidio, 2009, for intergroup misunderstandings), we examine how collective victimhood and acknowledgement of outgroup suffering are related to current-day social distance. These relationships are thought to be mediated by the group-based emotions of forgiveness and guilt. Furthermore, as historically differentiated victim and perpetrator representations are intertwined, we investigate how the representations of one event relate to the emotional reactions of the other.

\section{Effects of Collective Victimhood and Acknowledgement of Outgroup Suffering on Social Distance: The Mediating Role of Group-Based Guilt and Forgiveness}

Individuals experience collective emotions through group memberships even if they were not personally involved in an event (Mackie, Devos, \& Smith, 2000). Such emotions occur not only when one's own group has been mistreated but also when the ingroup has inflicted harm upon other groups (for overviews, see Iyer \& Leach, 2008; Nadler \& Shnabel, 2015). Importantly, for our purpose, collective emotional reactions have a long life, because research has shown that they can be triggered by ancient historical conflicts (e.g., Licata \& Klein, 2010; Mari, Andrighetto, Gabbiadini, Durante, \& Volpato, 2010, for the colonial past of a country) as well as by recent (e.g., Čehajić-Clancy, Effron, Halperin, Liberman, \& Ross, 2011) and ongoing 
conflicts (e.g., Halperin, 2011 ). As restoration of positive intergroup relations and reconciliation after an intergroup conflict is expected in modern democracies, it is crucial to uncover how group-based emotions may hinder or enhance these relations. We therefore examine the role of group-based forgiveness and guilt as key emotional reactions in the reconciliation process from the perspectives of both victim and perpetrator groups.

Intergroup forgiveness involves reductions of negative feelings such as anger and revenge towards the perpetrator group (Čehajić, Brown, \& Castano, 2008; Wohl \& Branscombe, 2005; for an overview Noor, Branscombe, \& Hewstone, 2015). However, collective victimhood-in particular when the victim role is exclusively associated with the ingroup-reduces willingness to forgive the perpetrator group (Hewstone et al., 2004; see Noor, Brown, Gonzalez, Manzi, \& Lewis, 2008; Vollhardt, 2015). For example, experience of collective victimhood during the ethno-political conflict in Northern Ireland known as the Troubles was related to reduced intergroup forgiveness (Noor et al., 2008). Yet, intergroup forgiveness offers a constructive way of addressing past wrongdoings by improving intergroup attitudes and willingness to reconcile (Noor et al., 2008; Staub, 2006). For example, among Jewish North Americans, higher levels of forgiveness towards contemporary Germans of the Holocaust have been shown to relate to reduced social distance (Wohl \& Branscombe, 2005). Čehajić et al. (2008), in turn, showed that Bosnian Muslims' readiness to forgive misdeeds committed by Bosnian Serbs during the 19921995 war in Bosnia and Herzegovina was negatively related to social distance towards Bosnian Serbs. We therefore expect that, overall, perceived collective victimhood should hinder the desire to forgive and consequently relate to increased social distance. Nevertheless, the motivations to forgive cannot be separated from the power asymmetry that defines the current-day relationship between the dominant Bulgarian majority and the subordinate Turkish minority. Its dominant, advantaged position may indeed bring the Bulgarian majority relatively closer to a perpetrator than victim view (Nadler \& Shnabel, 2015). The resulting motivation to be perceived moral and just may relate to a greater inclination to forgive compared to the subordinate, disadvantaged Bulgarian Turkish minority.

Members of perpetrator groups are expected to engage with their prior wrongdoings in order to acknowledge ingroup responsibility for causing outgroup victimization. This acknowledgement of ingroup responsibility provides a basis for feelings of group-based guilt, a group-level emotional response elicited by a conscious and articulate appraisal of the ingroup's historical wrongdoings (Branscombe \& Doosje, 2004). Acknowledgement of ingroup responsibility for unfair treatment further triggers willingness to make reparations (Čehajić-Clancy et al., 201 1; Iyer, Leach, \& Crosby, 2003; Mari et al., 2010) and to restore the groups' moral image (Nadler \& Shnabel, 2015).
Ingroup guilt has for example been associated with support for government policies favouring the indigenous community among nonindigenous Australians (McGarty et al., 2005) and for policies favouring African Americans among Whites in the U.S. (Iyer et al., 2003; see also Powell, Branscombe, \& Schmitt, 2005). Restoration of a positive image by seeking social connections should be particularly important for perpetrator groups that maintain a dominant position after the conflict (Nadler \& Shnabel, 2015), in our study the ethnic Bulgarians. Collective guilt should encourage ethnic Bulgarians to act prosocially and to foster harmonious intergroup relations by reducing social distance.

Nevertheless, some scholars have argued that because guilt is an aversive feeling, it may drive pro-social attitudes only to provide relief of this feeling (Imhoff, Bilewicz, \& Erb, 2012; see also Iyer et al., 2003). Similarly, seeing oneself as a descendant of a perpetrator group can foster intergroup anxiety (see Bilewicz, 2007). To downregulate anxiety, people withdraw and avoid interactions with the outgroup (e.g., Schmader \& Mendes, 2015). Hence, collective guilt can also be related to increased social distance. This process may be particularly prevalent among subordinate minorities, such as Bulgarian Turks, sensitive to threats resulting from stigmatization (see Hebl et al., 2009, for Blacks in the U.S.).

The distinction between victims and perpetrators is frequently ambiguous, however. In "dual" conflicts, both parties can take the perspective of victims at some point of the conflict and perpetrators at another point (Nadler \& Shnabel, 2015). This is the case for the Bulgarian majority and Bulgarian Turks. Victimhood and perpetratorhood at different moments in history are intertwined and can therefore also affect reactions and emotions related to another moment in history. Wohl and Branscombe (2008) showed for example that North American Jewish respondents who were reminded of the historical threat to their ingroup (i.e., the Holocaust) felt less guilt about harm inflicted on Palestinians in the Israeli-Palestinian conflict than those who were not reminded of their group's past victimization. Feeling that the ingroup has been victimized previously should thus reduce guilt in circumstances where one's ingroup has perpetrated wrongdoings. Similarly, we expect that acknowledgment of outgroup suffering caused by the ingroup should be associated with forgiveness towards the outgroup for their acts that took place at another moment in history.

\section{Current Research}

The purpose of this research is to study the consequences and representations of mutual ingroup victimhood and acknowledgement of outgroup suffering that took place at different historical periods. The research was conducted among ethnic Bulgarians and Bulgarian Turks in Kardzhali, a southern Bulgarian district strongly affected by the Rebirth 
process. The intergroup setting in Kardzhali is particular because the Bulgarian Turkish minority is the numerical majority. However, even in this region, compared to ethnic Bulgarians, Bulgarian Turks remain a lowerstatus, subordinate group, with higher unemployment rates $(13 \%$ vs. $22 \%)$ and lower levels of education $(5 \%$ vs. $23.2 \%$ with higher education; Bulgarian National Statistical Institute, 2012).

An embedded mixed method design (Creswell $\delta$ Plano Clark, 2007) was used where the outlined predictions were tested with cross-sectional survey data (Study l) and semi-directive interviews were conducted to gain depth in the interpretation of findings of the first study (Study 2). Study 1 examines the roles of groupbased forgiveness and collective guilt in the relationship between perceived collective victimhood and acknowledgment of outgroup suffering on the one hand and social distance on the other. In Study 2, we explore in more detail the meaning both groups provide for the events in which their groups were victims as well as transgressors.

\section{Study 1}

A set of mediation hypotheses were tested in Study 1. We predicted perceived collective victimhood (during the Ottoman period for ethnic Bulgarians and the Rebirth process for Bulgarian Turks) to be negatively associated with the desire to forgive the perpetrator group (see Figure 1 for relationships between concepts). Forgiveness, in turn, should be negatively related to social distance from the outgroup. We therefore expected an indirect relationship between victimhood and social distance through lowered forgiveness ( $\mathrm{Hl}$ ). We also explore whether the readiness to forgive is greater for the Bulgarian majority, because of their advantaged position in Bulgarian society, compared to the Turkish minority. Acknowledging outgroup suffering (Rebirth process for ethnic Bulgarians, Ottoman period for Bulgarian Turks), in turn, should be positively related to group-based guilt. As the literature points towards different consequences of guilt, we test opposing hypotheses as a function of intergroup power asymmetry: Group-based guilt can be expected to motivate relationship reparation by reducing social distance, but, as guilt is an aversive emotion, it may also increase social distance. We predict that acknowledgement is linked to collective guilt that is negatively (for the Bulgarian majority, $\mathrm{H} 2 \mathrm{a}$ ) and positively (for Bulgarian Turks, H2b) related to social distance. Furthermore, collective victimhood should be negatively related to group-based guilt of a temporally different era and thus be related to increased (for the Bulgarian majority, H3a) and reduced (for Bulgarian Turks, H3b) social distance. Conveying willingness for social connections (i.e., reduced social distance) because of group-based guilt can be a means for restoring a public moral image, and thus is more likely for the dominant ethnic Bulgarian group, whereas withdrawal in the form of social distance is more likely for the subordinate, Bulgarian Turk group. For both groups, acknowledgement of outgroup suffering, in turn, would relate to forgiving the outgroup for misdeeds at a temporally different era and thereby to reduced social distance (H4).

\section{Method}

Participants. Ethnic Bulgarians $(N=192)$ and Bulgarian Turks $(N=160)$ participated in a survey in June and July 2014. Data used in this study were part of a larger survey on interethnic relations in Bulgaria. A two-stage quota sampling strategy was used. First, sampling points were defined in urban and rural areas, and then eight respondents stratified by age and gender were sought from each point. The questions were administered in face-to-face interviews in Bulgarian language by professional interviewers. Respondents were provided with the necessary information for informed

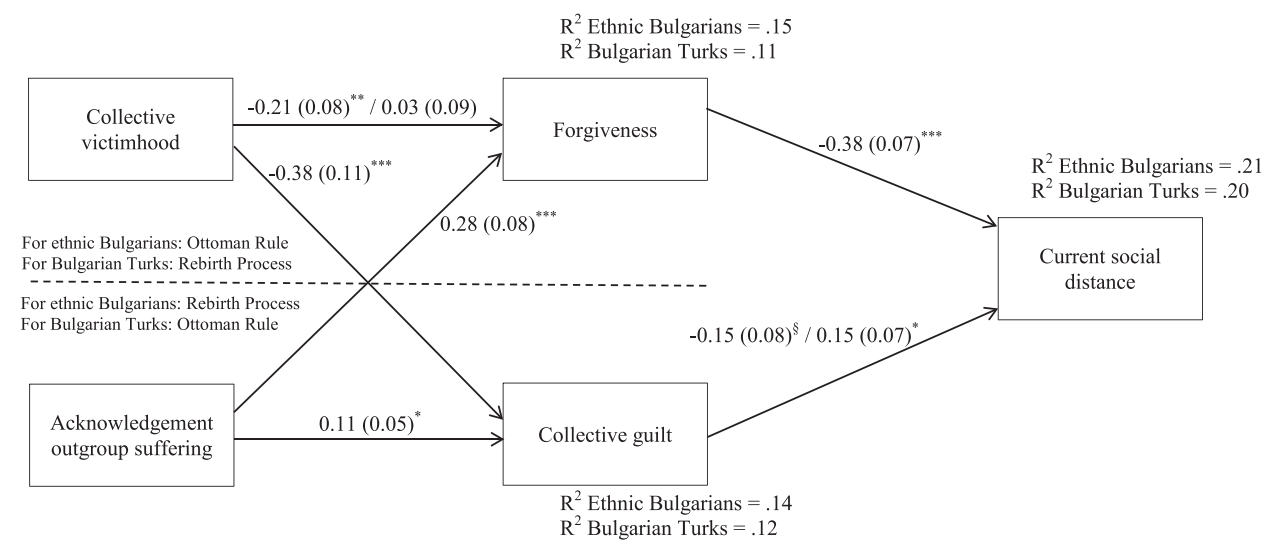

Fig. 1: Path analysis of the effects of collective victimhood and acknowledgement of outgroup suffering on social distance via forgiveness and collective guilt.

Note: Unstandardized coefficients (and standard errors) are reported. The clustered structure of the data was taken into account (Complex command in MPlus). When the two paths differ between ethnic Bulgarian and Bulgarian Turkish respondents, the coefficient for ethnic Bulgarians is reported first. Relations between collective victimhood and acknowledgement of outgroup suffering $r=-0.04(0.04), p=.218$; between forgiveness and collective guilt $r=-0.10(0.04), p=.007 .{ }^{\S} p=.061 .{ }^{*} p<.05 .{ }^{* *} p<.01 .{ }^{* * *} p \leq .001$ 
consent and guaranteed anonymity and that they could stop the interview at any time. In both subsamples, 50\% of respondents were women. Mean age was 44.51 $(S D=17.63)$ for ethnic Bulgarians and 45.25 $(S D=18.10)$ for Bulgarian Turks, $t(350)=0.51$, $p=.699$. Regarding educational level, $0.5 \%$ of ethnic Bulgarians had completed primary education only, $17.7 \%$ had completed lower secondary education, $50.5 \%$ had completed upper secondary education, and $31.3 \%$ had a degree above secondary education. For Bulgarian Turks, $5.0 \%$ had only a primary education degree or had not completed it, $23.8 \%$ had completed lower secondary education, $48.8 \%$ had completed upper secondary education and $22.5 \%$ had a degree above secondary education. Educational level was different in the two subsamples, $\chi^{2}(3)=10.91, p=.012$ : highlighting status asymmetry, ethnic Bulgarians were more educated than Bulgarian Turks. Respondents reported also the perception of "... the current economic situation of your family?" The response options ranged from 1 (We have enough money and are able to save) to 5 (We have to cut back on consumption and don't manage on our earnings). Bulgarian Turks $(M=3.11, S D=1.06)$ reported a worse economic situation than ethnic Bulgarians $(M=2.83, S D=1.06), t(350)=2.40, p=.017$.

Measures. All items were assessed on scales from 1 (completely disagree) to 5 (completely agree).

Collective victimhood. This was assessed with two items (adapted from Andrighetto, Mari, Volpato, \& Behluli, 2012). Ethnic Bulgarians responded to items referring to the Ottoman period ("Ethnic Bulgarians were harmed during the Ottoman Domination" and "During the Ottoman Domination, many ethnic Bulgarians suffered physical and psychological violence from Turks;" Spearman-Brown reliability statistic for a two-item measure: $\rho=.97)$, whereas Bulgarian Turks responded to victimhood regarding the Rebirth period with identically worded items $(\rho=.77)$.

Acknowledgement of outgroup suffering. This was measured with two items. Ethnic Bulgarians responded to items referring to the Rebirth period ("Bulgarian Turks were harmed during the Process of Rebirth" and “During the Process of Rebirth, many Bulgarian Turks suffered physical and psychological violence from ethnic Bulgarians;" $\rho=.86$ ), whereas Bulgarian Turks responded to identically worded items regarding acknowledgement of transgressions during the Ottoman period $(\rho=.86)$.

In both groups, collective victimhood was assessed prior to acknowledgment of ingroup responsibility.

Forgiveness. This was assessed with three items (adapted from Noor et al., 2008). Ethnic Bulgarians responded to items referring to the Ottoman period ("Ethnic Bulgarians should stop blaming Bulgarian Turks for what happened during the Ottoman Domination;" "Getting even with Bulgarian Turks for what happened during the Ottoman Domination is important"
[Reverse coded] and "Ethnic Bulgarians should seek ways of forgiving Bulgarian Turks to increase amity and understanding in Bulgaria;" $\alpha=.55$ ) whereas Bulgarian Turks responded regarding Rebirth period $(\alpha=.62)$. Albeit modest reliabilities, principal component analyses in both samples yielded a one-factor solution of the items measuring forgiveness.

Collective guilt. This was assessed with two items (adapted from Wohl \& Branscombe, 2005). Ethnic Bulgarians responded to items referring to the Rebirth period ("Ethnic Bulgarians should feel guilty about the process of Rebirth" and "Ethnic Bulgarians should feel guilty about what Bulgarian Turks experienced during the process of Rebirth;" $\rho=.81$ ), whereas Bulgarian Turks responded regarding the Ottoman period $(\rho=.87)$.

Social distance. This was assessed with three items (Bogardus, 1967) assessing the acceptance of the other ethnic community: "Would you accept Bulgarian Turks/ethnic Bulgarians as neighbours?", "Would you accept to work together with a Bulgarian Turk/ethnic Bulgarian?" and "Would you marry or cohabitate with a Bulgarian Turk/ethnic Bulgarian?" The three items $(\alpha=.65$ for ethnic Bulgarian respondents, $\alpha=.54$ for Bulgarian Turkish respondents) were reverse coded so that higher values indicated more social distance. Despite modest reliabilities, principal component analyses in both samples yielded a one-factor solution of the items assessing social distance.

\section{Results}

Preliminary Analyses. Means and standard deviations of the variables and correlations between them are reported in Table 1. Both ethnic Bulgarians and Bulgarian Turks perceived high levels of collective victimhood, but these feelings were stronger among ethnic Bulgarians, $t(330)=3.91, p<.001$. Both groups perceived to a similar degree that the outgroup had suffered, $t(339)=0.81, p=.418$. Furthermore, both ethnic communities reported more collective victimhood than perception of outgroup sufferings, $t(191)=13.29$, $p<.001$ for ethnic Bulgarians and $t(159)=13.13$, $p<.001$ for Bulgarian Turks. Thus, in line with the notion of competitive victimhood (Noor et al., 2008), both ethnic Bulgarians and Bulgarian Turks were aware of the two historical events and of the sufferings of both groups, but thought that their ethnic group had suffered more than the other one (see also Bilali \& Ross, 2012). Concerning emotions related to the historical events, both ethnic communities declared willingness to forgive past actions, but these feelings were stronger for Bulgarian Turks, the more disadvantaged group, than for ethnic Bulgarians, $t(347)=2.41, p=.016$. Perceptions of collective guilt were low in both ethnic communities and lower among ethnic Bulgarians than among Bulgarian Turks, $t(350)=3.70, p<.001$. Finally, social distance toward the other ethnic community was 
Table 1. Means and standard deviations of the variables and correlations between them, separately for ethnic Bulgarian ( $n=192)$ and Bulgarian Turkish $(n=160)$ respondents

\begin{tabular}{|c|c|c|c|c|c|c|c|c|c|}
\hline & \multicolumn{2}{|c|}{ Ethnic Bulgarians } & \multicolumn{2}{|c|}{ Bulgarian Turks } & \multirow[b]{2}{*}{1} & \multirow[b]{2}{*}{2} & \multirow[b]{2}{*}{3} & \multirow[b]{2}{*}{4} & \multirow[b]{2}{*}{5} \\
\hline & $M$ & $S D$ & $M$ & $S D$ & & & & & \\
\hline 1. Collective victimhood & 4.68 & 0.59 & 4.42 & 0.62 & - & -.07 & .00 & $-.26 * * *$ & .10 \\
\hline 2. Acknowledgement outgroup suffering & 3.47 & 1.06 & 3.39 & 0.73 & -.10 & - & $.33 * * *$ & .08 & $-.27^{\star * *}$ \\
\hline 3. Forgiveness & 3.67 & 0.82 & 3.86 & 0.62 & $-.17^{\star}$ & $.37 * * *$ & - & $-.26 * * *$ & $-.41 * * *$ \\
\hline 4. Collective guilt & 1.50 & 0.69 & 1.79 & 0.74 & $-.40^{* * *}$ & $.22 * *$ & .05 & - & $.29 * * *$ \\
\hline 5. Social distance & 2.46 & 0.74 & 2.00 & 0.62 & -.01 & $-.15^{\star}$ & $-.46^{* * *}$ & $-.16^{*}$ & - \\
\hline
\end{tabular}

Note.: Correlations between variables are reported below the diagonal for ethnic Bulgarian respondents and above the diagonal for Bulgarian Turkish respondents.

${ }^{*} p<.05$.

$* * p<.01$

$* * * p \leq .001$

relatively low, but ethnic Bulgarians perceived more social distance toward Bulgarian Turks than vice-versa, $t(350)=6.14, p<.001 .^{2}$

Multigroup Path Model. To test the hypothesized relationships between variables, we conducted a multigroup path analysis in Mplus 6 (Muthén \& Muthén, 1998-2010). Because of the clustered structure of the data (the 352 respondents were nested in 44 clusters, with eight respondents in each cluster), we used the Mplus Complex command, which provides estimates that are robust to non-independence and nonnormality of observations (Muthén \& Muthén, 19982010, p. 533). Collective victimhood and acknowledgement of outgroup sufferings were entered as predictors, group-based forgiveness and guilt as mediators, and social distance as the outcome variable. Because we expected that the effects of collective victimhood and perception of outgroup sufferings on social distance were explained by emotions related to historical events, we tested a fully mediated path model where the direct paths from predictors to the outcome variable were not estimated. Correlations between predictors and between mediators were estimated.

The initial path model, where all the paths were constrained to be equal between ethnic Bulgarian and Bulgarian Turkish respondents yielded modest fit indices, Satorra-Bentler scaled $\chi^{2}(12)=15.16, \quad p=.018$; RMSEA $=.077$, SRMR $=.069, \mathrm{CFI}=0.895$. We then released the paths one by one to examine whether they differed between the two groups. The Satorra-Bentler scaled $\chi^{2}$-difference test suggested that differences occurred between ethnic Bulgarian and Bulgarian Turkish respondents for the effect of collective victimhood on forgiveness, $\Delta \chi^{2}(1)=4.91, p=.027$, and for the effect of collective guilt on social distance, $\Delta \chi^{2}(1)=13.46$, $p<.001$. The model fit was not improved when further releasing equality constraints of other paths, SatorraBentler scaled $\Delta \chi^{2}(1) \mathrm{s}<1.86, p \mathrm{~s}>.172$.

\footnotetext{
${ }^{2}$ The degrees of freedom for some $t$-tests vary because variances were not homogeneous as indicated by Levene tests.
}

The final model with the two freed paths (Figure 1) yielded an adequate fit to the data: Satorra-Bentler scaled $\quad \chi^{2}(10)=7.75, \quad p=.189 ; \quad$ RMSEA $=.046$, SRMR $=.058, \mathrm{CFI}=0.969$. $^{3}$

To test whether collective victimhood and acknowledgement of outgroup suffering had the hypothesized indirect effects (i.e., mediation patterns) on social distance via group-based forgiveness and guilt, we added to the model the direct paths from the predictors to the outcome variable and calculated the indirect effects (Table 2). We first examined indirect effects through group-based emotions related to the same era. Collective victimhood was negatively associated to forgiveness, but only among ethnic Bulgarian respondents. Forgiveness, in turn, was negatively related to social distance. Thus, for ethnic Bulgarians, in line with $\mathrm{Hl}$, collective victimhood had a positive indirect relationship with social distance via reduced forgiveness. Moreover, acknowledgement of outgroup suffering was positively associated with collective guilt. The association between collective guilt and social distance was different for the two groups: collective guilt was negatively, albeit marginally, related to social distance among ethnic Bulgarians and positively related to social distance

\footnotetext{
${ }^{3}$ Additional analyses were conducted to control for the effects of sociodemographic characteristics. We thus ran the same multiple-group path analysis including gender, age, educational level and perception of the economic situation as control variables. This multiple-group path analysis was conducted without accounting for the clustered structure of the data, because of restraints in the ratio between number of clusters and number of parameters to estimate in the model. The results pattern was identical in essence to the reported model. For ethnic Bulgarians, a more advantageous economic situation was related to forgiveness $(B=0.16, S E=0.06, p=.006)$ and less social distance $(B=-0.20, S E=0.04, p<.001)$. Females expressed more social distance than men $(B=-0.20, S E=0.09, p=.021)$, older people expressed more social distance $(B=0.01, S E=0.003, p=.029)$ and educational level was negatively related to social distance $(B=-0.22$, $S E=0.07, p=.001)$. For Bulgarian Turks, a more advantageous economic situation $(B=0.09, S E=0.04, p=.030)$ and higher education $(B=0.15, S E=0.06, p=.012)$ were related to forgiveness. A more advantageous economic situation was also linked to guilt $(B=0.13$, $S E=0.05, p=.014)$ and higher educational level to less social distance $(B=-0.15, S E=0.05, p=.004)$.
} 
Table 2. Indirect effects of collective victimhood and of acknowledgement of outgroup sufferings on social distance via forgiveness and collective guilt

\begin{tabular}{llll}
\hline Predictor & \multicolumn{1}{c}{ Mediator } & \multicolumn{1}{c}{ Ethnic Bulgarians } & Bulgarian Turks \\
\hline $\begin{array}{l}\text { Same historical era mediation } \\
\text { H1 Collective victimhood }\end{array}$ & Forgiveness & $B=0.08, S E=0.03, p=.018$ & $B=-0.01, S E=0.03, p=.700$ \\
H2 Acknowledgement outgroup suffering & Collective guilt & $B=-0.03, S E=0.01, p=.073$ & $B=0.02, S E=0.01, p=.039$ \\
$\begin{array}{l}\text { Different historical era mediation } \\
\text { H3 Collective victimhood }\end{array}$ & Collective guilt & $B=0.09, S E=0.04, p=.040 \quad B=-0.08, S E=0.03, p=.011$ \\
H4 Acknowledgement outgroup suffering & Forgiveness & $B=-0.11, S E=0.03, p=.001$ & $B=-0.11, S E=0.03, p=.001$ \\
\hline
\end{tabular}

Note.: Unstandardized coefficients and standard errors are reported. Bootstrapping cannot be implemented with the Complex command in Mplus.

among Bulgarian Turks. Thus, acknowledgement of outgroup suffering had a negative indirect relationship with social distance via collective guilt among ethnic Bulgarians (in support of $\mathrm{H} 2 \mathrm{a}$ ), whereas the indirect relationship was positive for Bulgarian Turks (in support of H2b). Next, we turn to indirect effects through emotions related to temporarily different eras. As expected, collective victimhood was negatively associated to collective guilt of a temporally different period. For ethnic Bulgarians, collective victimhood had a positive indirect relationship with social distance via collective guilt related to a temporally different event (in support of H3a), while for Bulgarian Turks the indirect relationship was negative (in support of $\mathrm{H3b}$ ). Acknowledgement of outgroup suffering was related to forgiveness of a temporally different event. Confirming H4, in both groups, acknowledgement of outgroup suffering had negative indirect relationships with social distance via forgiveness for a temporally different event.

\section{Study 1 Discussion}

In line with our predictions, group-based guilt and forgiveness mediated the relationship between collective victimhood and acknowledgement of outgroup suffering on the one hand and social distance on the other for both ethnic Bulgarians and Bulgarian Turks. Nevertheless, some differences occurred. Among Bulgarian Turks, the expected negative link between collective victimhood and forgiveness was not found. Moreover, as predicted, the two groups had opposite relations between group-based guilt and social distance. For the ethnic Bulgarians, the dominant majority group, feeling guilt about the Rebirth process that took place in the mid-1980s was related to less social distance. This suggests that reduced social distance could be conceived as a means to restore the moral image of the ingroup by repairing the current relationship between the groups. It should be noted, however, that reparation via reduced social distance occurs on an interpersonal level and does not involve official acknowledgments and reparations; hence, the status quo of power relations between groups is not questioned (e.g., Shnabel, Halabi, \& SimanTov-Nachlieli, 2015 for counterproductivity of reparation acts). For the subordinate Bulgarian Turkish minority, in support of the conjecture that guilt is an aversive emotion triggering intergroup anxiety (Imhoff et al., 2012), experiencing guilt of an era that ended 140 years ago, was related to increased social distance.

The high levels of collective victimhood-higher than that of the minority-suggest that the Bulgarian majority still sees itself as a victim of historical injustice. Bulgarian Turks were more willing to forgive than ethnic Bulgarians. As a dominant majority position can engender readiness to forgive, we anticipated that ethnic Bulgarians would be more inclined to forgive compared to subordinate Bulgarian Turks (Nadler \& Shnabel, 2015). Nevertheless, it may be that the fact that the subordinate group was actually the numeric majority in the district under study has counteracted this effect. To further interpret findings of Study 1 and to uncover the different ways of representing collective victimhood and acknowledging outgroup suffering inflicted by the ingroup, semi-directive interviews were conducted in Study 2.

\section{Study 2}

The goal of this study was to explore in more depth the meaning people give to past ingroup victimhood and ingroup responsibility in outgroup victimization and thus gain insights on the findings of Study 1 (Creswell \& Plano Clark, 2007). Ingroup representations of historical events define group identity and the relationships with outgroups. Given the varying temporality of events and differences in terms of group status and role in conflict, it is plausible that history is interpreted differently by the dominant Bulgarian majority and the subordinate Turkish minority (Liu \& Hilton, 2005). Indeed, the memories of the 500 years of Ottoman rule that ended in the late $19^{\text {th }}$ century are not based on personal experience, whereas the Rebirth period is quite recent, with many respondents having first or at least secondhand information on this period.

\section{Method}

Twenty semi-directive interviews were conducted among ethnic Bulgarians and Bulgarian Turks (10 each). The interviewees were drawn among survey respondents of Study 1 who agreed to take part in a follow-up interview that took place four to six weeks later. Participants were sampled at equal gender distribution. Mean age was 48 years for ethnic Bulgarians (range 23 - 65 years) and 45 years for Bulgarian Turks 
(range $23-72$ years). The interviewer and interviewee ethnicity were matched to facilitate discussion of ingroup victimhood and misdeeds. The ethnic Bulgarian interviews were conducted by two Bulgarian PhD students involved in the research project, while the Bulgarian Turkish interviews were performed by a psychologist collaborating in the project. Interviews lasted between 21 and 66 minutes. After the interview, interviewees received a $15 \mathrm{Lev}$ incentive (corresponding to circa 7.5 euros). All interviews were audiotaped and later transcribed verbatim. The data corpus was further translated into English by professional translators under the supervision of the Bulgarian research team.

We wanted the participants to engage in both descriptive and interpretative work and examined any references to the ingroup victimhood and outgroup suffering as well as contrasts within and between the two groups. The dataset was analysed with theoretically guided thematic coding (Braun \& Clarke, 2006). First, the material was read and re-read, and next an initial coding was generated. Third, the codes were organized into themes, and finally the themes were reviewed and revised by checking them against the coded extracts. Different themes were identified in the data for the two groups.

\section{Results and Discussion}

Victimhood Representations. All the ethnic Bulgarian and most Bulgarian Turk interviewees evoked victimhood resulting from the Ottoman Rule and the Rebirth policies, respectively, when asked of a moment in history when their group was victimized. Underscoring the prevailing power asymmetry between two groups, members of these groups portrayed victimhood very differently, however. Among ethnic Bulgarians, ingroup victimhood crystallized into a narrative of nation-building, whereas for Bulgarian Turks it was a theme of suffering with a no-longer existing perpetrator.

Ethnic Bulgarians reiterated the official narrative referring to atrocities, massacres and forced turkization (i.e., conversion to Islam) during the Ottoman rule. They actively drew on the historical " evidence " portrayed by the media, school books and cultural productions, thereby consensually adhering to the shared representation (Reicher \& Hopkins, 2001). Much like in other contexts (Bar-Tal et al., 2009; see Liu \& Hilton, 2005), this victimhood narrative was crystallized around defining the victim-the ethnic Bulgarians-and the perpetrator-Ottoman Turks-and often concluded with the (heroic) survival of the nation (Todorova, 2004). The association between Ottoman Turks and Bulgarian Turks of today was implicit, although some interviewees explicitly differentiated the two.

Extract 1. "Well, I remember, when this movie was launched-The Goat Horn [1972, set in $17^{\text {th }}$ century Bulgaria; authors' comments in square brackets], you see the opposite side. When we watched it, then we really felt hatred for...you see, it was at the time of socialism, you see, somehow we felt hatred in some way." Ethnic Bulgarian male, 65 years

Extract 2. "Well, generally said, this was an event which each country should be proud of, in my opinion, because it was at the time that we realized our national identity, and also we survived as a nation." Ethnic Bulgarian female, 39 years

After the communist era, the word choices in the official narrative have changed, for example, the term "Ottoman Slavery " has been gradually replaced by "Ottoman Domination/Rule» and even "Ottoman Presence», deemphasizing the culpability of the current Bulgarian Turkish population (Parvev, 2014). However, some interviewees commented on this change of narrative contesting the supposed rewriting of history. For them, the new terminology does not accurately portray the events-it does not fit the narrative of nationbuilding victimhood-thereby suggesting that the shared representation of history is not without controversy (Pashova et al., 2013; Liu \& Hilton, 2005).

Extract 3. "[...] not as of now, for example, when they are distorted in history books, saying that these events didn't happen, that it was just an invasion and so on. This domination over us lasted a lot of years." Ethnic Bulgarian female, 39 years

Without doubt because of the temporal proximity, the Bulgarian Turk interviewees presented more personal accounts of the Rebirth process, frequently referring to their own or their (grand-)parents' experiences. While Bulgarian Turks evoked the forced name changes, loss of property and exile to Turkey (i.e., the official description of the policy and the known consequences), their accounts also conveyed grievances resulting from harassment, beating, imprisonment and hiding. Their narratives were thus more affective than those of ethnic Bulgarians. While some ethnic Bulgarians expressed anger when discussing the Ottoman regime, Bulgarian Turks conveyed suffering, fear and sadness resulting from this period (Bar-Tal et al., 2009; Noor et al., 2012; Vollhardt, 2012).

Extract 4. "In 1984-85 when we were made to change the names, it was terrible, we weren't going out, we were hiding." Bulgarian Turkish male, 46 years

At the same time, the victimhood accounts of Bulgarian Turks were more nuanced than those of the ethnic Bulgarians. The communist political system (president of the time, Todor Zhivkov, the parliament, the Soviet Union and its president) was throughout the interviews systematically held responsible, and ethnic Bulgarian people were hardly mentioned as active perpetrators (although a few did evoke the possibility that some ethnic Bulgarians, as bystanders, may have agreed with the events). Instead, events of ethnic Bulgarians' helping behaviour were recalled. Previous research has also reported such testimonies of war victims (Broz, Kain Hart, \& Elias-Bursac, 2005). Acknowledging helping could be seen as an expression of loyalty and common ingroup membership with ethnic Bulgarians, who were under the rule of the same 
totalitarian communist system (Noor et al., 2008; see also Reicher, Cassidy, Wolpert, Hopkins, \& Levine, 2006). Thus, the groups shared victimhood (Vollhardt, 2015, for inclusive victimhood). Such victimhood representations thus not only serve to explain the past (Bar-Tal et al., 2009), but they may also empower the Bulgarian Turks through conceptions of common ingroup membership (see Nadler \& Shnabel, 2015, on the importance of restoration of agency for disadvantaged groups). In these multifaceted representations of collective victimhood, ethnic Bulgarians were dissociated from the totalitarian system-the common perpetrator-some as helpers, others as bystanders. This representation of inclusive victimhood by Bulgarian Turks may explain the lack of relationship between collective victimhood and forgiving the ethnic Bulgarians found in Study 1. Inclusive victimhood is also another plausible reason for the higher levels of forgiveness of the Bulgarian Turkish minority (Shnabel, Halabi, \& Noor, 2013), in addition to the regional majority explanation of Bulgarian Turks in the district under study.

Extract 5. "My grandmother and uncle told me. We had a lot of Bulgarian friends who somehow were hiding them. Saved them from being beaten or arrested. I do thank them all." Bulgarian Turkish male, 23 years

Extract 6. "Bulgarians, because they were more informed, they warned us; there were such times where because of a word (even unintentionally said) you could be put to Belene prison [notorious prison and labour camp during the communist era in Northern Bulgaria], I have a lot of colleagues who were put there because they were against this process." Bulgarian Turkish male, 58 years

Acknowledging Ingroup Transgressions. Ethnic Bulgarian interviewees acknowledged the existence of the Rebirth era by mentioning for example name change policies or the mass exodus to Turkey. Consistent with the Bulgarian Turks' accounts, the political system was depicted as responsible for the occurrence of the Rebirth process. For ethnic Bulgarians, the Rebirth was the doings of the prevailing political system -without acknowledging that individuals actively took part in implementing the Rebirth policies (see Noor et al., 2012, for biases in accounts of ingroup transgressions). The Rebirth process was seen as being politically instrumentalized prior to elections in present-day Bulgaria, in particular by the Movement of Rights and Freedoms (MRF) party, whereas the current intergroup relations were conceived as positive. This instrumentalization was acknowledged by some Bulgarian Turks too.

Extract 7. "I don't think that it is discussed among people. It is already in the past, just politicians raise the issue again and again for their own reasons and purposes" Ethnic Bulgarian female, 66 years

Extract 8. "I don't know, now it seems that everything is slowly being forgotten, but politicians act in a way people do not forget it. Maybe they call the attention to it, all Turks are associated with the MRF party. This tears us apart, people live very well together if these people are not around." Bulgarian Turkish female, 49 years

However, while most interviewees acknowledge the period as a horrible mistake, some question the gravity either by saying events were exaggerated or by justifying the imposition of Bulgarian language in Bulgaria. They morally disengage from the events (Nadler $\delta$ Shnabel, 2015). Similar to "hiding behind" the political system, legitimizing to some extent the events, people avoid acknowledging the ingroup members' role in the Rebirth process. Čehajić and Brown (2008) found similar narrative strategies used by Serbian interviewees conveying unwillingness to acknowledge harmdoing committed by ingroup (see also Bilali $\delta$ Ross, 2012; Čehajić-Clancy et al., 2011). Also, in guise of justification because of past ingroup victimization (Bar-Tal et al., 2009), parallels were made with the Ottoman period in line with the idea that past victimization can reduce guilt of a more recent event where the ingroup is the transgressor (Liu \& Hilton, 2005; Wohl $\delta$ Branscombe, 2008). Indeed, the movie "Time of Violence", evoked by an interviewee, was presented in 1988 when the Rebirth process policies were implemented, and described how forced Islamization of Bulgarians took place during the Ottoman period. Such cultural products most likely mobilized the Bulgarian national identity and provided justification of the events at that time.

Extract 9. “[...] their names were changed, but I don't think that it was forced. I don't think that it was something uncivilized, because finally, you see when you go to another country, for example the USA, the first name becomes John, you see...There are other countries where their names aren't changed, but when they see that a foreigner has a name that is typical for this country, it is better accepted by society. So, I don't think that it was forcibly done. It was rather a necessity for that period of time." Ethnic Bulgarian male, 38 years

Though the Bulgarian Turks were aware of the official narrative of the Ottoman rule in Bulgaria, they referred less to the accounts in books and films when acknowledging it. As the Ottoman Turks are strongly stigmatized in these accounts and by extension Bulgarian Turks are associated with them, the hegemonic representation of national history leaves Bulgarian Turks the role of the villain. Interviewees noted that the events took place hundreds of years ago, so it was hard to define who was actually responsible. They also reported being targets of ethnic Bulgarians' blame and hate, in particular by older generations of ethnic Bulgarians who have been the most exposed to the official nation-building narrative of the Ottoman presence and thus most likely to associate Bulgarian Turks with Ottoman perpetrators.

Extract 10. "This idea [responsibility of Turks] comes right from school, where we study the Ottoman rule. These materials must step by step be removed from school books. There is let's say the Batak massacre [of 
Bulgarians], and other things, young people should not be raised in this way, taught that the Turk is their worst enemy" Bulgarian Turkish male, 45 years

Outgroup victimhood was seen by ethnic Bulgarians as politically motivated at the time and currently politicized, whereas Bulgarian Turks saw it as a catalyst for ingroup stigmatization. All in all, both groups dismissed their ingroup's role in outgroup victimhood (Bilali $\&$ Ross, 2012; Noor et al., 2012). The power asymmetry underlies differences in representations. Ethnic Bulgarians' national identity is constructed through victimhood and survival during the Ottoman regime, but they disidentify from the communist regime that they see as the sole responsible for the Rebirth process. Nevertheless, as the assimilationist policies were implemented by ethnic Bulgarians, albeit under the orders of the communist Bulgarian government, guilt may have arisen and favoured a tendency for reparation, for example by means of reduced social distance as revealed in Study 1. Despite distancing themselves from the Ottoman Turks, Bulgarian Turks, in turn, carry the imposed burden of responsibility of the victimization of ethnic Bulgarians as they are associated with oppressors in the collective narrative. Accepting collective guilt for this era may be irreconcilable with being part of a common Bulgarian nation ${ }^{4}$ and would thus be a catalyst for distancing themselves from ethnic Bulgarians (note though that mean levels of guilt were low in Study 1). Indeed, the positive relationship between collective guilt and social distance revealed among Bulgarian Turks in Study 1 can be interpreted in this way (Imhoff et al., 2012).

\section{General Discussion}

This study contributes to the literature of intergroup conflicts by examining the role of collective victimhood and acknowledgement of ingroup misdeeds on social distance in parallel for a dominant national majority (ethnic Bulgarians) and a subordinate national minority (Bulgarian Turks). Both groups have been victims and perpetrators in intergroup conflicts in different historical eras. Despite a complex intergroup configuration among ethnic groups in Bulgaria and the presence of past conflict in contemporary public discourse, until now, surprisingly little social psychological research has examined this context. The mixed-methods study allowed investigating representations about two historical eras during which power relations between the two rival groups have been inverted, giving rise to the current power asymmetry between the groups.

Study 1 revealed that, for ethnic Bulgarians, collective victimhood inflicted by the Ottoman regime (that ended in the $19^{\text {th }}$ century) was related to increased social distance with Bulgarian Turks through reduced

\footnotetext{
${ }^{4}$ Note that Bulgarian Turks do identify with Bulgaria. Assessed with a three-item scale $(1=$ not at all, $5=$ yes, very $m u c h ; \alpha=.83)$, identification with Bulgaria was relatively high $(M=3.59, S D=0.93)$ and different from the scale midpoint (3), $t(159)=7.99, p<.001$.
}

forgiveness and through reduced guilt for forced assimilation of Bulgarian Turks during the 1980s. Acknowledgment of outgroup suffering, in turn, was related to decreased social distance through heightened guilt and through forgiveness for actions perpetrated during the Ottoman period. Among Bulgarian Turks, the result pattern was different. Collective ingroup victimhood because of Rebirth policies was unrelated to forgiveness, but was linked to reduced social distance through decreased guilt related to the Ottoman period. Perceptions of outgroup suffering during the Ottoman period, in turn, were related to increased guilt and thereby to increased social distance.

Through the interviews in Study 2, we examined the differential meanings the dominant majority and subordinate minority gave to the events, thereby yielding insights for the two different result patterns of Study 1 . Among ethnic Bulgarians, victimhood because of the Ottoman regime was used as a rhetoric nation-building device, whereas among Bulgarian Turks victimhood resulting from the Rebirth process was more nuanced, with the ethnic Bulgarians' perpetrator role being questioned. In both groups, outgroup victimization was diluted. For ethnic Bulgarians, outgroup victimization during the Rebirth process was essentially described as politically motivated and currently politicized notably by the MRF party. For Bulgarian Turks, outgroup victimization during the Ottoman rule was seen as a rhetoric strategy by ethnic Bulgarians to justify stigmatization of Bulgarian Turks.

The interpretation of findings of this research must be situated within the particular context in which the study took place. Collective memories are largely shaped by the surrounding political culture and changing political interests. The transition from a totalitarian communist system to a more democratic post-communist system represents the historical backdrop of this study. Indeed, the two historical eras considered in this paper were interlinked in the political project of the socialist regime. The interview findings among the ethnic Bulgarians in Study 2 echoed the collective nationalist narrative of the Ottoman period that was constructed for bringing the nation together and strategically employed by the system to legitimize Rebirth policies. After the transition, from the 1990s onward, anti-communist attitudes became widespread. A large majority of all Bulgarians, including the ethnic majority as well as the Turkish minority, distanced themselves from the former communist government and its forced assimilation campaigns. In addition to explaining why the Bulgarian Turks were more inclined to forgive the ethnic Bulgarians than vice versa, this may explain why ethnic Bulgarians' guilt for the Rebirth process was downplayed by both sides. But even though Bulgarian Turks regained rights after the transition and anti-discrimination laws exist now, the power asymmetry between the groups has not fundamentally changed. With economic scarcity and political instability, nostalgia for communism has also emerged. This nostalgia has revived nationalist attitudes pitting the national majority against the minorities. Though 
Bulgarian Turks do not demand reparations, the MRF party makes such requests on their behalf. Nonetheless, the Rebirth process has attracted little attention in the public which may go some way in explaining why these requests are not deemed legitimate by the ethnic Bulgarian majority.

The shared heroic nation-building narrative of the Bulgarian nation persists despite changes in official accounts. Even though most ethnic Bulgarians readily acknowledge that current-day Bulgarian Turks have no responsibility for the events of the Ottoman period, some Bulgarian Turks may feel guilt, possibly as the result of a pervasive political narrative strategically imposed upon them. The findings of Study 1 indeed suggest that experiencing guilt triggers distancing oneself from the majority group.

Our findings on representations of these specific historical events beg the question of generalizability. At least two distinct dimensions may be useful to consider in future studies on intergroup reconciliation. First, representations of temporally differentiated victimization events in which victim and perpetrator status have been inverted and their role in current-day intergroup relations can be examined in other intergroup contexts as well. A case in point are formerly occupied countries in which a current minority can be linked to the former occupying group. This is the case, for example, for the Russian minority in Estonia: during the communist period, Russians were the dominant group within Estonia, but in current-day Estonia they are a subordinate group and have suffered severe forms of stigmatization. Second, a direct comparison between historical representations of a dominant majority group and a subordinate minority group adds an important dimension to the victim-perpetrator antagonism. We would argue that these two antagonisms (victim-perpetrator and dominant-subordinate groups) are orthogonal. On the one hand, a former victim group can become a dominant group (Jews in Israel) and a former perpetrator group can become a subordinate group (Russians in Estonia). On the other hand, however, a former perpetrator group may maintain its dominant position and the victim group its subordinate place (albeit being the numeric majority) as in South Africa after the end of apartheid. Accordingly, the reconciliation processes at work may reflect joint motivations derived from both the victim-perpetrator and the dominant-subordinate status of the groups.

\section{Limits and Conclusions}

Some caveats of the current research must be noted. First, as the empirical evidence is based on crosssectional survey data and semi-directive interviews, firm causal claims cannot be made. Nevertheless, the multigroup path model tested in Study 1 drew on theorizing and findings from prior research on collective emotions and victimhood, thereby increasing our confidence in these findings. Moreover, the triangulation of quantitative and qualitative data, revealing the relationships between concepts as well as differential meanings assigned to the events by the two groups, underscored the prevailing power asymmetry between groups as well as the temporal asymmetry of the events. This richer understanding of the phenomenon offsets to some extent the disadvantage of not being able to draw unequivocal causal conclusions. Experimental research would nevertheless be useful to establish causality. An interesting avenue for future experiments would be to examine, for both a subordinate minority and a dominant majority group, whether the outgroup's acknowledgment of ingroup victimization counteracts the detrimental impact of collective victimhood in decreasing forgiveness and increasing social distance.

Second, the scales used in Study l were shortened from the original scales assessing the concepts, partially explaining the low reliability of the social distance and forgiveness constructs. As this was because of the overall length of the survey covering different aspects of interethnic relations in Bulgaria, future studies on collective victimhood in Bulgaria would do well in using more complete scales.

Third, the order in which the questions were asked both in the survey and in the semi-directive interviews may have biased some responses. Ingroup victimhood questions always preceded those of acknowledgement of outgroup suffering. This question order may have accentuated the finding that outgroup suffering was minimized compared to ingroup victimhood (Bilali \& Ross, 2012). Prior research has indeed shown that people feel morally less obliged to repair wrongdoings when reminded of ingroup suffering (Wohl $\delta$ Branscombe, 2008).

By studying the mutual impact of historical conflicts on intergroup relations in Bulgaria, our research highlights the importance of examining in parallel the perspective of both victims and perpetrators across time. Moreover, it demonstrates the dynamic aspect of intergroup relations shaped by intergroup conflicts occurring over history in which the role of the victims and perpetrators are inverted. Indeed, different historical events and current-day intergroup attitudes are intertwined. Today, while the power asymmetry between the groups remains, there is no overt conflict between ethnic Bulgarians and Bulgarian Turks and intergroup relations are reasonably harmonious. Nevertheless, the representations of history differ between the groups. Parts of the conflictual history essential to the victimhood of the subordinate minority are "forgotten", while other parts central to the victimhood of the dominant majority "survive". Thus, reconciliation is yet to occur.

\section{Acknowledgements}

This research was supported by the Swiss National Science Foundation (Grant IZEBZ0_142998) with Eva G.T. Green as PI. The first two authors contributed equally to this article. The authors declare that there are no potential conflicts of interest with respect to the research, authorship and/or publication of this article. 


\section{References}

Andrighetto, L., Mari, S., Volpato, C., \& Behluli, B. (2012). Reducing competitive victimhood in Kosovo: The role of extended contact and common ingroup identity. Political Psychology, 33, 513-529.

Bar-Tal, D., Chernyak-Hai, L., Schori, N., \& Gundar, A. (2009). A sense of perceived collective victimhood in intractable conflicts. International Review of the Red Cross, 91, 229-258.

Bilali, R., \& Ross, M. (2012). Remembering intergroup conflict. In L. R. Tropp (Ed.), The Oxford handbook of intergroup conflict (pp. 123-135). New York, NY: Oxford University Press.

Bilewicz, M. (2007). History as an obstacle: Impact of temporal-based social categorizations on Polish-Jewish intergroup contact. Group Processes $\theta$ Intergroup Relations, 10, 551-563.

Bogardus, E. S. (1967). A forty-year racial distance study. Los Angeles, CA: University of Southern California Press.

Branscombe, N. R., \& Doosje, B. (Eds) (2004). Collective guilt: International perspectives. New York, NY: Cambridge University Press.

Braun, V., \& Clarke, V. (2006). Using thematic analysis in psychology. Qualitative Research in Psychology, 3, 77-101.

Broz, S., Kain Hart, L., \& Elias-Bursac, E. (2005). Good people in an evil time: Portraits of complicity and resistance in the Bosnian war. New York, NY: Other Press.

Bulgarian National Statistical Institute (2012). Census of Population and Housing in 2011, Volume 3 Districts, Book 9 Kardzhali [Преброяване На Населението И Жилищния Фонд През 2011 Година, Том 3 Области, Книга 9 Кърджали]. Retrieved from: http://statlib.nsi.bg:8181/ isisbgstat/ssp/fulltext.asp?content=/FullT/FulltOpen/ P_22_2011_T3_KN9.pdf

Čehajić, S., \& Brown, R. (2008). Not in my name: A social psychological study of antecedents and consequences of acknowledgment of ingroup atrocities. Genocide Studies and Prevention, 3, 195-212.

Čehajić, S., Brown, R., \& Castano, E. (2008). Forgive and forget? Antecedents and consequences of intergroup forgiveness in Bosnia and Herzegovina. Political Psychology, 29, 351-368.

Čehajić-Clancy, S., Effron, D., Halperin, E., Liberman, V., \& Ross, L. (2011). Affirmation, acknowledgment of ingroup responsibility, group-based guilt, and support for reparative measures. Journal of Personality and Social Psychology, 101, 256-270.

Crampton, R. J. (1997). A concise history of Bulgaria. Cambridge, United Kingdom: Cambridge University Press.

Creswell, J. W., \& Plano Clark, V. L. (2007). Designing and conducting mixed methods research. Thousand Oaks, CA: Sage Publications.

Demoulin, S., Leyens, J.-P., \& Dovidio, J. F. (Eds) (2009). Intergroup misunderstanings. Impact of divergent social realities. New York, NY: Psychology Press.

Elcheva, M (2005). Alien by default: The identity of the Turks of Bulgaria at home and in immigration. In R. Detrez \& P. Plas (Eds.), Developing cultural identity in the Balkans: Convergence vs. divergence (pp. 87-110). Brussels, Belgium: Peter Lang
Halperin, E. (2011). Emotional barriers to peace: Emotions and public opinion of Jewish Israelis about the peace process in the Middle East. Peace and Conflict, 17, 22-45.

Hebl, M., Dovidio, J. F., Richeson, J. A., Shelton, N. J., Gaertner, S. L., \& Kawakami, K. (2009). Interpretation of interaction: Responsiveness to verbal and non-verbal cues. In S. Demoulin, J.-P. Leyens \& J. F. Dovidio (Eds.), Intergroup misunderstandings: Impact of divergent social realities (pp. 101-1 16). New York, NY: Psychology Press.

Hewstone, M., Cairns, E., Voci, A., McLernon, F., Niens, U., \& Noor, M. (2004). Intergroup forgiveness and guilt in Northern Ireland: Social psychological dimensions of "The Troubles." In N. Branscombe \& B. Doosje (Eds.), Collective guilt: International perspectives (pp. 193-215). New York, NY: Cambridge University Press.

Imhoff, R., Bilewicz, M., \& Erb, H. (2012). Collective regret versus collective guilt: Different emotional reactions to historical atrocities. European Journal of Social Psychology, 42, 729-742.

Iyer, A., \& Leach, C. W. (2008). Emotion in inter-group relations. European Review of Social Psychology, 19, 86-125.

Iyer, A., Leach, C. W., \& Crosby, F. J. (2003). White guilt and racial compensation: The benefits and limits of self-focus. Personality and Social Psychology Bulletin, 29, 117-129.

Licata, L., \& Klein, O. (2010). Holocaust or benevolent paternalism? Intergenerational comparisons on collective memories and emotions about Belgium's colonial past. International Journal of Conflict and Violence, 4, 45-57.

Liu, J. H., \& Hilton, D. J. (2005). How the past weighs on the present: Social representations of history and their role in identity politics. British Journal of Social Psychology, 44, 537-556.

Mackie, D. M., Devos, T., \& Smith, E. R. (2000). Intergroup emotions: Explaining offensive action tendencies in an intergroup context. Journal of Personality and Social Psychology, 79, 602-616.

Mari, S., Andrighetto, L., Gabbiadini, A., Durante, F., \& Volpato, C. (2010). The shadow of the Italian colonial experience: The impact of collective emotions on intentions to help the victims' descendants. International Journal of Conflict and Violence, 4, 58-74.

McGarty, C., Pedersen, A., Leach, C. W., Mansell, T., Waller, J., \& Bliuc, A. M. (2005). Collective guilt as a predictor of commitment to apology. British Journal of Social Psychology, 44, 659-680.

Mudde, C. (2005). Racist extremism in Central and Eastern Europe. East European Politics and Societies, 16, 161-184.

Muthén, L. K., \& Muthén, B. O. (1998-2010). Mplus user's guide (Sixth ed.). Los Angeles, CA: Muthén \& Muthén.

Nadler, A., \& Shnabel, N. (2015). Intergroup reconciliation: Instrumental and socioemotional processes and the needs-based model. European Review of Social Psychology, 26, 93-125.

Noor, M., Branscombe, N., \& Hewstone, M. (2015). When group members forgive: Antecedents and consequences. Group Processes $\theta$ Intergroup Relations, 18, 577-588.

Noor, M., Brown, R., Gonzalez, R., Manzi, J., \& Lewis, C. A. (2008). On positive psychological outcomes: What helps groups with a history of conflict to forgive and reconcile with each other? Personality and Social Psychology Bulletin, 34, 819-832.

Noor, M., Shnabel, N., Halabi, S., \& Nadler, A. (2012). When suffering begets suffering: The psychology of competitive 
victimhood between adversarial groups in violent conflicts. Personality and Social Psychology Review, 16, 351-374.

Pamporov, A. (2010). The employment of Roma, Turks and Bulgarians. A comparative report based on the outcome of the Multipurpose Household Survey 2007. In M. Stewart \& M. Rovid (Eds.) Multi-disciplinary approaches to Romany studies (pp.131-154). Budapest, Hungary: CEU press.

Parvev, I. (2014). Southeastern Europe from within: Balkan studies at the University of Sofia, 1989-2010. Challenge and perspectives. In C. Promitzer, S. Gruber, \& H. Heppern (Eds.). Southeast European studies in a globalizing world (pp. 161-170). Wien, Austria: Lit Verlag.

Pashova, A., Popova, K., Piskova, M., Angelova, M., Muratova, N., \& Vodenicharov, P. (2013). 'Battles in the past' or 'Battles for the past': Bulgarian national models of memory and memory policy. Balkanistic Forum, 1, 34-55.

Powell, A. A., Branscombe, N. R., \& Schmitt, M. T. (2005). Inequality as ingroup privilege or outgroup disadvantage: The impact of group focus on collective guilt and interracial attitudes. Personality and Social Psychology Bulletin, 31, 508-521.

Reicher, S. D., Cassidy, C., Wolpert, I., Hopkins, N., \& Levine, M. (2006). Saving Bulgaria's Jews: An analysis of social identity and the mobilisation of social solidarity. European Journal of Social Psychology, 36, 49-72.

Reicher, S. D., \& Hopkins, N. (2001). Self and nation: Categorization, contestation and mobilisation. London, UK: Sage.

Schmader, T., \& Mendes, W. B. (2015). Putting feelings in a social context: Three case studies applying Gross's extended model of emotion regulation. Psychological Inquiry, 26, 116-122.

Shnabel, N., Halabi, S., \& Noor, M. (2013). Overcoming competitive victimhood and facilitating forgiveness through re-categorization into a common victim or perpetrator identity. Journal of Experimental Social Psychology, 49, 867-877.

Shnabel, N., Halabi, S., \& SimanTov-Nachlieli, I. (2015). Group apology under unstable status relations: Perceptions of insincerity hinder reconciliation and forgiveness. Group Processes $\theta$ Intergroup Relations, 18, 716-725.

Sidanius, J., \& Pratto, F. (1999). Social dominance: An intergroup theory of social hierarchy and oppression. New York, NY: Cambridge University.

Staub, E. (2006). Reconciliation after genocide, mass killing, or intractable conflict. Political Psychology, 27, 867-894.

Todorova, M. (2004). Conversion to Islam as a trope in Bulgarian historiography, fiction and film. In M. Todorova (Ed.), Balkan identities: Nation and memory (pp. 129-157). New York, NY: New York University Press.

Vollhardt, J. R. (2012). Collective victimization. In L. Tropp (Ed.), Oxford handbook of intergroup conflict (pp. 136-157). New York, NY: Oxford University Press.

Vollhardt, J. R. (2015). Inclusive victim consciousness in advocacy, social movements, and intergroup relations: Promises and pitfalls. Social Issues and Policy Review, 9, 89-120.

Weaver, C. N. (2008). Social distance as a measure of prejudice among ethnic groups in the United States. Journal of Applied Social Psychology, 38, 779-795.

Wohl, M. J. A., \& Branscombe, N. R. (2005). Forgiveness and collective guilt assignment to historical perpetrator groups depend on level of social category inclusiveness. Journal of Personality and Social Psychology, 88, 288-303.

Wohl, M. J. A., \& Branscombe, N. R. (2008). Remembering historical victimization: Collective guilt for current ingroup transgressions. Journal of Personality and Social Psychology, 94, 988-1006. 